\title{
Effect of Fractioning on Antibacterial Activity of Enantia chlorantha Oliver (Annonaceae) Methanol Extract and Mode of Action
}

\author{
Rebeca Ebelle Etame, ${ }^{1}$ Raymond Simplice Mouokeu ${ }^{D},{ }^{2}$ \\ Cedric Laurel Cidjeu Pouaha, ${ }^{3}$ Igor Voukeng Kenfack, ${ }^{4}$ Raphael Tchientcheu, ${ }^{3}$ \\ Jean Paul Assam Assam, ${ }^{3}$ Frank Stève Monthe Poundeu, ${ }^{3}$ Alembert Tchinda Tiabou, ${ }^{1}$ \\ François Xavier Etoa, ${ }^{5}$ Jules Roger Kuiate $\mathbb{D D}^{4}{ }^{4}$ and Rosalie Anne Ngono Ngane ${ }^{3}$ \\ ${ }^{1}$ Institute of Medical Research and Medicinal Plant Studies (IMPM), P.O. Box 6163, Yaoundé, Cameroon \\ ${ }^{2}$ Institute of Fisheries and Aquatic Sciences, University of Douala, P.O. Box 7236, Douala, Cameroon \\ ${ }^{3}$ Faculty of Sciences, University of Douala, P.O. Box 24157, Douala, Cameroon \\ ${ }^{4}$ Faculty of Sciences, University of Dschang, P.O. Box 67, Dschang, Cameroon \\ ${ }^{5}$ Faculty of Sciences, University of Yaoundé I, P.O. Box 812, Yaoundé, Cameroon
}

Correspondence should be addressed to Raymond Simplice Mouokeu; moraysi@yahoo.fr

Received 28 November 2017; Revised 19 March 2018; Accepted 1 April 2018; Published 29 April 2018

Academic Editor: Nativ Dudai

Copyright (c) 2018 Rebeca Ebelle Etame et al. This is an open access article distributed under the Creative Commons Attribution License, which permits unrestricted use, distribution, and reproduction in any medium, provided the original work is properly cited.

Infectious diseases caused by bacteria constitute the main cause of morbidity and mortality throughout the world and mainly in developing countries. In this work, the influence of fractioning and the mode of action of stem barks methanol extract of Enantia chlorantha were investigated. The aim was to optimize the antibacterial activity of the methanol extract. The extract was prepared by maceration of barks powder in methanol. Fractioning was done using increasing solvents polarity. Standard phytochemical methods were used for phytochemical screening. Minimum Inhibitory Concentrations (MIC) and Minimum Bactericidal Concentration (MBC) of the methanol extract and fractions were determined using broth microdilution method. The studied mode of action of both methanol extract and n-butanol fraction included antibiofilm activity, H+-ATPase-mediated proton pumping assay, salt tolerance, and cells cycle. The methanol extract of E. chlorantha stem barks was found to be active on all the bacteria tested ( $32 \leq$ MIC $\leq 512 \mu \mathrm{g} / \mathrm{mL}$ ), its activity being significant (MIC $<100 \mu \mathrm{g} / \mathrm{ml}$ ) out of 5 of the 28 clinical isolates used. Salmonella enterica serovar paratyphi A was the most sensitive $(32 \mu \mathrm{g} / \mathrm{mL})$. Compared to the extract and other fractions, the n-butanol fraction was found to be more active $(32 \leq \mathrm{MIC} \leq 256)$. Significant antibacterial activity of this fraction was observed out of 10 of the 28 bacterial isolates and 3 out of 7 bacterial strains. Lowest MIC values $(32 \mu \mathrm{g} / \mathrm{ml})$ of this fraction were obtained with Escherichia coli (136), Pseudomonas aeruginosa (CIP 76110), and Salmonella enterica serovar typhi 9. The methanol extract of E. chlorantha and its n-butanol fraction revealed several modes of action including the prolongation of the latency phase of the bacterial growth, the inhibition of the pump with protons $\mathrm{H}^{+}$- ATPases bacterial, the loss of the salt tolerance of the Staphylococcus aureus, and inhibition of the formation of the bacterial biofilm. The present results showed that the n-butanol fraction of the methanol stem barks extract of E. chlorantha possess the essential antibacterial components and could best be used to fight against bacterial infections as compared to methanol extract.

\section{Introduction}

Infectious diseases caused by bacteria constitute a public health problem all over the world and particularly in Africa where living conditions are precarious $[1,2]$. The discovery of antibiotics has been a real relief for humanity because they have greatly reduced the incidence of infectious diseases [3]. The often inappropriate prescription of antibiotics and their inappropriate use by the population among others have led to selection pressure by bacteria [4]. This has led, for 
several decades, to the emergence of resistant bacteria, which is the main cause of increased frequency of therapeutic failures, mortality, and high costs of treatment [5]. Alternative remediation could include new antimicrobial substances that are effective, available, and low in toxicity. Medicinal plants are a credible research pathway. Indeed, they are rich in molecules of an exceptional chemical variability making them a vast reservoir of substances that can act through various modes of action [6]. Many approaches have so far been used to demonstrate the antibacterial activity of plants. They include crude extract preparation using variety of solvents [7], purification of active compounds from extracts [8-11], successive extraction with solvents with increasing polarity [12], and distillation. Solvent extraction has been the most used method but recent studies established increased activity with fractionation of crude extract $[13,14]$. In addition, many African countries with poor technology are limited for production of medicine from pure active compounds or their derivatives. Alternative could be formulation of best active plant extract or their fractions.

Enantia chlorantha is a plant belonging to the Annonaceae family. It is highly prized in the traditional Cameroonian pharmacopoeia and used in the treatment of several infections including malaria, anemia, typhoid fever, and yellow fever [15]. Also called Epoue (Baka), Peye (Badjoue), and Nfol (Bulu), it is widely spread along Sub-Saharan Africa [16]. The stem barks, leaves, and roots are used in Africa to treat jaundice, urinary infection, and leprosy spots. They are also used as hemostatic agents and uterus stimulants [17]. Previous studies highlighted antimicrobial, antimycobacterial, antiviral, antioxidant, antipyretic, and antisickin activity [18]. The present work was initiated to improve the antibacterial activity of the methanol extract and to explore possible mechanism of bactericidal action.

\section{Materials and Methods}

\subsection{Materials}

2.1.1. Plant Material. The barks of E. chlorantha were collected at Kalla Mountain, Central Region of Cameroon. The plant was identified at the National Herbarium (Yaoundé, Cameroon) where a voucher specimen was deposited under the reference number 45569/HNC.

2.1.2. Chemicals. Chloramphenicol (Sigma-Aldrich, St. Quentin Fallavier, France) was used as reference antibiotic. p-Iodonitrotetrazolium chloride (INT) was used as microbial growth indicator.

2.1.3. Bacteria Strains, Clinical Isolates, and Culture Media. The antibacterial activities of crude extract and fractions were carried out on 7 strains and 28 clinical isolates. The clinical isolates of Escherichia coli, Enterobacter aerogenes, Klebsiella pneumoniae, and Staphylococcus aureus were obtained from patient suffering from the gastroenteritis at the Bafang ADLUCEM hospital. The isolate of Salmonella enterica serovar typhi, Salmonella enterica serovar paratyphi A, Salmonella enterica serovar paratyphi B, and Salmonella enterica serovar typhimurium were obtained from the Laboratory of Bacteriology and Mycology of the "Centre Pasteur" Yaoundé-Cameroon. Methicillin-resistant Staphylococcus aureus strains were obtained from the culture collection of the Laboratory of Microbiology, Graduate School of Pharmaceutical Sciences, University of Tokyo, Japan. Multidrug resistant Providencia stuartii strain was obtained from the culture collection of the University of Mediterranean, France. The bacterial features are summarized in Table 1 [19-22].

These microorganisms were maintained at $4^{\circ} \mathrm{C}$ on Mueller Hinton Agar (MHA) (Liofilchem, Italy). Mueller Hinton Broth (MHB) (Liofilchem, Italy) was used for Minimum Inhibitory Concentrations (MIC) and Minimum Bactericidal Concentrations (MBC) determination.

\subsection{Methods}

2.2.1. Extract Preparation and Fractioning. E. chlorantha barks were dried for 14 days and powdered. $1 \mathrm{~kg}$ dry powder was soaked in $5 \mathrm{~L}$ methanol for 48 hours at room temperature and then filtered using Whatman filter paper number 1 . The filtrate obtained was concentrated at $45^{\circ} \mathrm{C}$ under reduced pressure in a vacuum to obtain plant extract (7.91\%).

Fractionation of the methanol extract of dry powder of E. chlorantha barks was done using successive partitions. In so doing, $80 \mathrm{~g}$ methanol extract was dissolved in $300 \mathrm{~mL}$ distilled water and shacked vigorously in the presence of $500 \mathrm{~mL}$ hexane and was allowed to decant. The hexane phase was further collected and the process repeated twice. The same process was repeated with ethyl acetate and n-butanol and the hexane, ethyl acetate, and n-butanol phases were concentrated at $45^{\circ} \mathrm{C}$ under reduced pressure in a Rota vapor. The residual fraction was dried for two days at $45^{\circ} \mathrm{C}$ in a stove.

\subsubsection{In Vitro Antibacterial Activity}

(a) Preparation and Standardization of Inocula. The inoculum of each bacterium was prepared by dilution in distilled water, three to four colonies obtained from 18 hours culture on $\mathrm{MHA}$ at $37^{\circ} \mathrm{C}$. These microbial suspensions were diluted to match the 0.13 optical density at $600 \mathrm{~nm}$ corresponding to 1.5 $\times 10^{6} \mathrm{CFU} / \mathrm{mL}$ using a Genesys $20 \mathrm{UV} / \mathrm{Vis}$ spectrophotometer.

(b) INT Colorimetric Assay for Minimum Inhibitory Concentrations (MIC) and Minimum Bactericidal Concentrations $(M B C)$ Determination. The inhibitory potential of bacteria growth by methanol extract and fractions from $E$. chlorantha was determined by broth microdilution method in 96well microtiter plates [23]. The MIC assay was conducted using INT colorimetric assay according to Eloff [24] with slight modifications. Test samples or chloramphenicol was dissolved in dimethylsulfoxide (DMSO). A serial twofold dilution was performed to obtain final concentrations ranging from 16 to $1024 \mu \mathrm{g} / \mathrm{mL}$. Each well was further diluted with $100 \mu \mathrm{l}$ inoculum. The plates were incubated at $37^{\circ} \mathrm{C}$ for $18 \mathrm{~h}$. The assay was repeated thrice. Wells containing adequate broth, bacterial inoculum, and DMSO to a final concentration of $2.5 \%$ served as negative control. Following 
TABLE 1: Bacteria strains and clinical isolates feature used in the study.

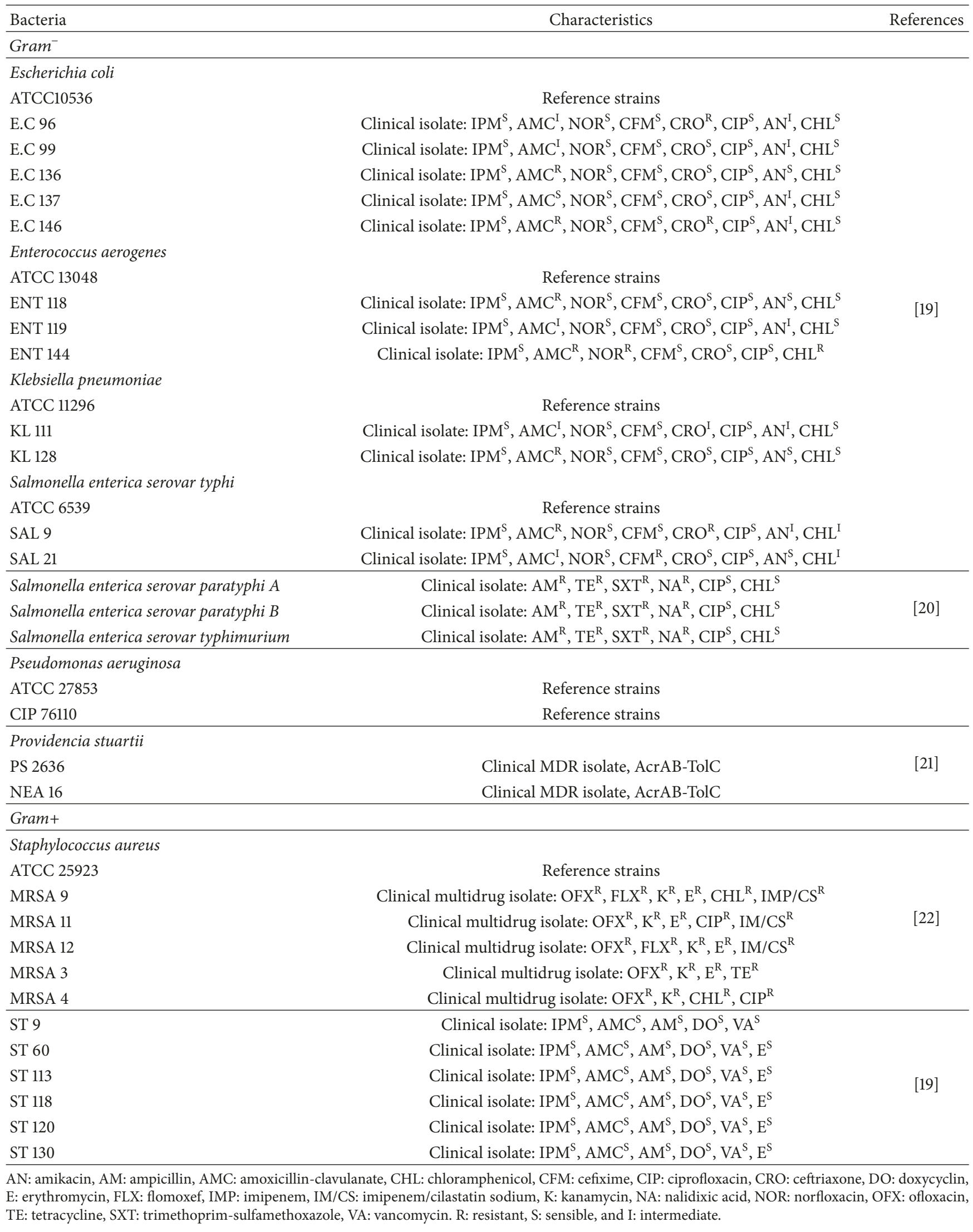


incubation, $40 \mu \mathrm{L}$ of $0.2 \mathrm{mg} / \mathrm{mL}$ INT was added in each well. Plates were further incubated for additional $30 \mathrm{~min}$ at $37^{\circ} \mathrm{C}$. Viable bacteria reduced the yellow dye of INT to a pink color. MIC values were defined as the sample concentration that prevented the color change of INT that exhibited complete inhibition of bacterial growth [25].

The MBC values were determined by adding $50 \mu \mathrm{l}$ aliquots of the preparations which did not show any growth after incubation during MIC assays to $150 \mu \mathrm{L}$ broth culture medium. These preparations were incubated at $37^{\circ} \mathrm{C}$ for $48 \mathrm{~h}$. The MBC values were regarded as the lowest concentration of extracts which did not produce any color change after addition of INT as mentioned above [26]. The tests were done in triplicate and repeated thrice.

\subsubsection{Antibacterial Mechanisms Study}

(a) Bacteria Cell Growth. The effect of methanol extract and n-butanol fraction from E. chlorantha on E. coli and S. aureus cell growth was performed according to Darah et al. [27] with some modifications. Bacterial suspensions were prepared as described previously. Extract or n-butanol fraction was added to conical plates containing $23 \mathrm{~mL}$ of sterilized Mueller Hinton Broth culture medium and inoculum $\left(1.5 \times 10^{6} \mathrm{CFU} / \mathrm{mL}\right)$. The final concentrations of the extracts in the plates were half MIC, MIC, and 2 MIC. Plates containing only culture media and those containing culture media and bacteria suspension constitute negative control, while plates containing chloramphenicol at MIC were considered as positive control. The experiments were performed in triplicate and all the plates were incubated at $37^{\circ} \mathrm{C}$ under agitation at $150 \mathrm{rpm}$. After the incubation period corresponding to $t=0 \mathrm{~min}, 30 \mathrm{~min}, 1 \mathrm{~h}, 2 \mathrm{~h}$, $4 \mathrm{~h}, 6 \mathrm{~h}, 8 \mathrm{~h}, 10 \mathrm{~h}, 12 \mathrm{~h}, 14 \mathrm{~h}, 16 \mathrm{~h}$, and $18 \mathrm{~h}$, the optical density of each flask was recorded at $600 \mathrm{~nm}$ using BIOBASE UVVIS spectrophotometer. All the measurements were done in triplicate.

(b) $\mathrm{H}^{+}$-ATPase-Mediated Proton Pumping. The proton pumping activities of $E$. coli and $S$. aureus were determined by monitoring glucose-induced acidification of the external medium [28]. Briefly, $100 \mathrm{~mL}$ bacteria culture was grown in Muller Hinton broth culture for 18 hours at $37^{\circ} \mathrm{C}$. The resulting culture was centrifuged at $3500 \mathrm{~g}$ for $10 \mathrm{~min}$. The pellet was washed twice with distilled water and then with $50 \mathrm{mM} \mathrm{KCl}$ and resuspended in $50 \mathrm{~mL}$ of $50 \mathrm{mM} \mathrm{KCl}$. The cell suspension was incubated overnight $(18 \mathrm{~h})$ at $4^{\circ} \mathrm{C}$ for glucose starvation and then centrifuged and diluted to achieve absorbance of 8 at $600 \mathrm{~nm}$. In $4 \mathrm{~mL}$ of the reaction medium, $0.5 \mathrm{~mL}$ methanol extract of E. chlorantha or nbutanol fraction at half MIC, MIC, and 2 MIC were added and the $\mathrm{pH}$ adjusted to 6.4. Upon $10 \mathrm{~min}$ preincubation at $37^{\circ} \mathrm{C}$, medium acidification was initiated with addition of glucose $20 \%(0.5 \mathrm{~mL})$ followed by $\mathrm{pH}$ measurement after each $10 \mathrm{~min}$ for $2 \mathrm{~h}$. DMSO $2.5 \%$ was used as control. The experiment was performed in triplicate and repeated thrice.

(c) Loss of Salt Tolerance in Staphylococcus aureus. The ability of S. aureus ATCC 25923 and S. aureus ST 120 cells treated with methanol extract and n-butanol fraction to grow on Mueller Hinton agar (MHA) supplemented with $\mathrm{NaCl}$ was investigated. In preliminary experiments, untreated suspensions of $S$. aureus were plated on MHA supplemented with $\mathrm{NaCl}$ from 40 to $100 \mathrm{mg} / \mathrm{mL}$. Plates were incubated and upon incubation, the resulting colonies were counted. Concentrations of $\mathrm{NaCl}, 60,70$, and $75 \mathrm{mg} / \mathrm{mL}$, that modestly compromised the colony-forming abilities were selected. For further experimentation steps, suspensions of bacteria were prepared as described previously and treated with extract of $E$. chlorantha and n-butanol fraction at half MIC, $\mathrm{MIC}$, and $2 \mathrm{MIC}$. After $1 \mathrm{~h}$ incubation period, samples were inoculated on MHA plates supplemented with $\mathrm{NaCl}(60,70$, and $75 \mathrm{mg} / \mathrm{mL}$ ). Bacterial culture without extract was used as control for each $\mathrm{MHA}-\mathrm{NaCl}$ plate. Upon incubation, the mean number of colony-forming units $/ \mathrm{mL}$ on agar medium was reported [29].

(d) Biofilm Formation. Biofilm assays were conducted based on the method described by O'Toole and Kolter [30] with slight modifications. Bacteria cell suspensions were prepared as described previously. In sterile 96-well culture plates, containing $100 \mu \mathrm{L}$ of Mueller Hinton Broth, $100 \mu \mathrm{L}$ extract or n-butanol fraction solution was added in the first well. A serial twofold dilution was performed to obtain final concentration range of $1 / 2$ MIC to 8 MIC. $100 \mu \mathrm{L}$ of fresh bacterial suspension was added. After $24 \mathrm{~h}$ incubation at $37^{\circ} \mathrm{C}$, the content of each well was gently removed by tapping the plates. The wells were washed with $200 \mu \mathrm{L}$ sterile saline to remove free-floating bacteria and then dried and fixed at $65^{\circ} \mathrm{C}$ for $1 \mathrm{~h}$. Biofilms formed by adherent cells in plates were stained with $0.8 \%$ crystal violet and incubated at room temperature for 20 minutes. Excess stains were rinsed off by thorough washing with deionized water and plates were fixed with $200 \mu \mathrm{L}$ of $30 \%$ acetic acid. Growth control (cells + broth), media control (only broth), and blank control (broth + extract) were included in the assay. Optical densities (OD) of stained adherent bacteria were measured at $630 \mathrm{~nm}$ using an ELISA microplate reader. The percentage of biofilm inhibition was calculated using the following formula: [(OD growth control - OD sample)/OD growth control] $\times 100$ [31] All tests were performed in triplicate and repeated twice.

\subsubsection{Phytochemical Screening of Methanol Extract and} Fractions. The presence of alkaloids, triterpenes, sterols, flavonoids, polyphenols, and saponins was screened according to the common phytochemical methods described by Harbone [32].

2.2.5. Statistical Analysis. The statistical analysis was performed using Statistical Package for the Social Sciences (SPSS) version 20.0 (SPSS, Inc., Chicago, IL, USA). One-way ANOVA and Duncan's multiple range tests were done and the results were considered significant at probability $p<0.05$.

\section{Results and Discussion}

3.1. Antibacterial Activity. The methanol extract and fractions from stem bark of $E$. chlorantha were evaluated for their antibacterial activities on a panel of bacteria including 
TABLE 2: Effect of fractioning of E. chlorantha methanol extract on MICs/MBCs $(\mu \mathrm{g} / \mathrm{mL})$ values.

\begin{tabular}{|c|c|c|c|c|c|c|}
\hline Bacteria & Extract & n-Hexane & Ethyl acetate & n-Butanol & Residual & $\mathrm{CHL}$ \\
\hline \multicolumn{7}{|l|}{ E. coli } \\
\hline ATCC 10536 & $128 / 256$ & $512 /-$ & $256 / 1024$ & $128 / 256$ & $128 / 512$ & $4 / 64$ \\
\hline EC 136 & $128 / 512$ & $512 /-$ & $256 / 512$ & $32 / 256$ & $64 / 512$ & $32 / 256$ \\
\hline EC 137 & $128 / 256$ & 1024/- & $256 / 1024$ & $64 / 256$ & $64 / 512$ & 64/- \\
\hline EC 99 & $128 / 256$ & 1024/- & $128 / 512$ & $64 / 256$ & $64 / 512$ & $32 / 128$ \\
\hline EC 96 & $512 / 1024$ & $512 /-$ & $256 /-$ & $128 / 256$ & $256 / 512$ & $32 / 128$ \\
\hline EC 146 & $64 / 128$ & $512 /-$ & 1024/- & $128 / 256$ & $512 / 1024$ & $32 / 256$ \\
\hline \multicolumn{7}{|l|}{ E. aerogenes } \\
\hline ATCC 13048 & $128 / 256$ & $256 /-$ & $512 /-$ & $256 / 512$ & $256 / 256$ & $8 / 128$ \\
\hline ENT 119 & $64 / 1024$ & $256 / 1024$ & $256 / 1024$ & $64 / 512$ & $128 / 512$ & $16 / 128$ \\
\hline ENT 118 & $512 / 1024$ & 1024/- & 256/- & $128 / 1024$ & $256 / 1024$ & $128 /-$ \\
\hline ENT 144 & $128 / 256$ & 1024/- & $512 /-$ & $256 / 256$ & $256 / 512$ & $32 / 64$ \\
\hline \multicolumn{7}{|l|}{ K. pneumoniae } \\
\hline ATCC 11296 & $128 / 512$ & $512 /-$ & $256 /-$ & $128 / 512$ & $128 / 512$ & $8 / 64$ \\
\hline KL 128 & $128 / 512$ & 1024/- & $256 /-$ & $64 / 256$ & $32 / 256$ & $32 / 128$ \\
\hline KL 111 & $128 / 512$ & 1024/- & $256 / 1024$ & $128 / 512$ & $256 / 512$ & $32 /-$ \\
\hline S. enterica serovar paratyphi $A$ & $32 / 256$ & $128 / 512$ & $128 / 512$ & $64 / 256$ & $256 / 1024$ & $16 / 64$ \\
\hline S. enterica serovar paratyphi $B$ & $128 / 512$ & $256 /-$ & $64 / 1024$ & $64 / 128$ & $128 / 1024$ & $8 / 128$ \\
\hline S. enterica serovar typhimurium & $128 /-$ & $-/-$ & $-/-$ & $256 /-$ & $512 /-$ & $32 / 128$ \\
\hline \multicolumn{7}{|l|}{ S. enterica serovar typhi } \\
\hline ATCC 6539 & $128 / 512$ & $512 / 1024$ & $256 /-$ & $64 / 256$ & $128 / 1024$ & $64 / 256$ \\
\hline SAL 9 & $128 / 512$ & $512 / 1024$ & $512 /-$ & $32 / 512$ & $128 / 1024$ & $32 / 128$ \\
\hline SAL 21 & $256 / 512$ & $512 /-$ & $256 /-$ & $128 / 512$ & $128 /-$ & $64 /-$ \\
\hline \multicolumn{7}{|l|}{ P. aeruginosa } \\
\hline ATCC 27853 & $128 / 512$ & $256 /-$ & $1024 /-$ & $128 / 512$ & $128 / 512$ & $16 / 128$ \\
\hline CIP 76110 & $128 / 1024$ & $256 /-$ & $64 /-$ & $32 / 256$ & $32 / 256$ & $4 / 32$ \\
\hline \multicolumn{7}{|l|}{ P. stuartii } \\
\hline PS 2636 & $128 / 1024$ & $-/-$ & $-/-$ & $256 /-$ & $512 /-$ & $32 /-$ \\
\hline NEA 16 & 64/- & $-/-$ & $-/-$ & $256 /-$ & $256 /-$ & $8 / 256$ \\
\hline \multicolumn{7}{|l|}{ S. aureus } \\
\hline ATCC 25923 & $256 / 512$ & $512 /-$ & $256 / 512$ & $128 / 256$ & $128 / 512$ & $32 / 128$ \\
\hline ST 120 & $64 / 512$ & $-/-$ & $512 / 512$ & $64 / 256$ & $64 / 512$ & $8 / 64$ \\
\hline ST 113 & $128 /-$ & 1024/- & $256 /-$ & $64 / 512$ & $128 /-$ & $16 / 64$ \\
\hline ST 9 & $256 / 1024$ & $512 /-$ & $256 /-$ & $128 / 256$ & $128 /-$ & 32128 \\
\hline ST 118 & $256 / 1024$ & 1024/- & $256 /-$ & $128 / 1024$ & $256 / 512$ & $64 / 128$ \\
\hline ST 130 & $128 / 512$ & $512 /-$ & $128 / 1024$ & $128 / 1024$ & $128 / 1024$ & $4 / 64$ \\
\hline ST 60 & $256 / 1024$ & 1024/- & 128/- & $64 / 512$ & 64/- & $8 / 128$ \\
\hline MRSA 9 & $256 / 512$ & 1024/- & 1024/- & $128 / 512$ & $512 /-$ & $128 /-$ \\
\hline MRSA 11 & $256 / 1024$ & $512 /-$ & $512 /-$ & $128 / 512$ & $512 / 1024$ & $32 / 128$ \\
\hline MRSA 12 & $512 / 1024$ & 1024/- & $512 /-$ & $128 / 1024$ & 256/- & $64 / 64$ \\
\hline MRSA 4 & 256/- & $-/-$ & $-/-$ & 256/- & $256 /-$ & $8 / 64$ \\
\hline MRSA 3 & $256 /-$ & $-/-$ & $-/-$ & $256 /-$ & $512 /-$ & $32 / 128$ \\
\hline
\end{tabular}

$\mathrm{CHL}=$ chloramphenicol, $-=$ MIC or MBC was greater than 1024 .

strains (7) and clinical isolates (28). The results are reported in Table 2.

The methanol extract of this plant was active on all the strains and isolates tested with MIC values ranging from 32 to $512 \mu \mathrm{g} / \mathrm{mL}$. Significant activity was obtained with $5 / 25$ clinical isolates used. The lowest value of $32 \mu \mathrm{g} / \mathrm{mL}$ was obtained with
S. enterica serovar paratyphi A. Moreover, antibacterial activity of this extract was obtained on multiresistant S. enterica serovar paratyphi isolates, S. enterica serovar typhimurium, and $S$. aureus.

The fractionation of crude extract of E. chlorantha made it possible to obtain four fractions with varying degrees of 

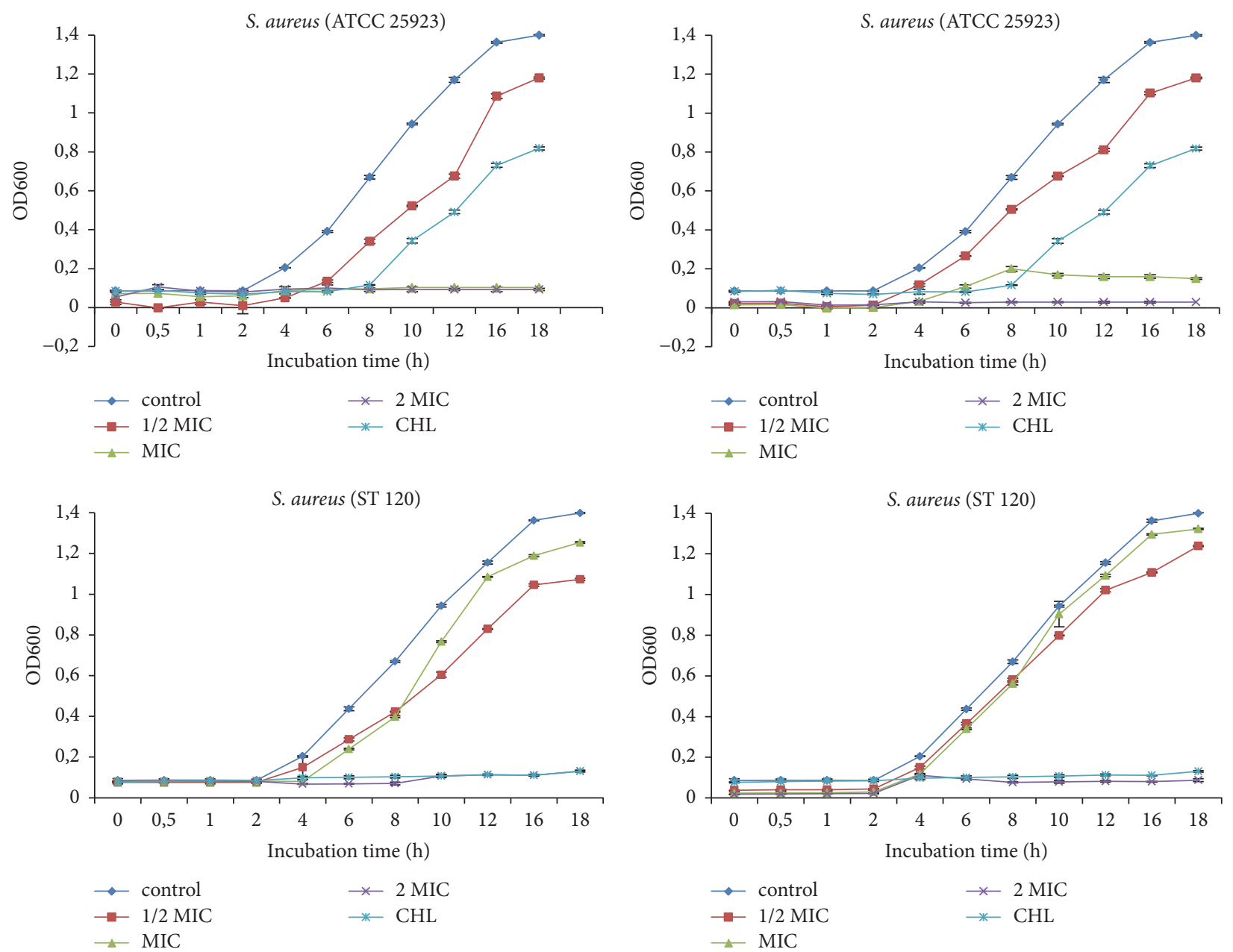

(a)

(b)

FIGURE 1: Effect of E. chlorantha methanol extract (a) and its n-butanol fraction (b) on Staphylococcus aureus growth as a function of time. CHL: chloramphenicol; MIC: minimum inhibitory concentration. Data are expressed as mea, $n=3$.

antibacterial activity (Table 2). n-Hexane and ethyl acetate fractions were found to be less active with $\mathrm{MIC}<1024 \mu \mathrm{g} / \mathrm{mL}$ obtained on 29/35 and 30/35 35 tested bacteria, respectively. Compared to these fractions, the $\mathrm{n}$-butanol and residual fractions were most active with MIC values ranging from $32 \mu \mathrm{g} / \mathrm{mL}$ to $512 \mu \mathrm{g} / \mathrm{mL}$. Significant activity (MIC $<100 \mu \mathrm{g} / \mathrm{mL}$ ) was obtained with $13 / 35$ and $7 / 35$ bacteria, respectively, with $\mathrm{n}$-butanol and residual fractions. Lowest MIC $(64 \mu \mathrm{g} / \mathrm{mL})$ was obtained with n-butanol fraction on $S$. enterica serovar typhi (SAL 9), P. aeruginosa (CIP 76110), and E. coli (EC 136).

\subsection{Mechanism of Antibacterial Activity}

3.2.1. Inhibition of Bacteria Cell Growth. Figures 1-2 showed the influence of extracts on the growth curves of $S$. aureus and $E$. coli. In general, the E. chlorantha extract and fraction inhibited bacterial cell growth depending on the concentrations and microorganisms. At 1/2 MIC, inhibition of bacterial cell growth was observed after 4 to 6 hours following treatment. At MIC and 2 MIC, inhibition was maximal with prolongation of the latency phase. Furthermore, at these concentrations, both extract and fraction produced cell eradication after $12 \mathrm{~h}$.

3.2.2. Inhibition of H+-ATPase-Mediated Proton Pumping. The methanol extract of $E$. chlorantha bark and its n-butanol fraction independently of the concentration inhibited the bacterial $\mathrm{H}+$-ATPase proton pumps (Figures 3-4). This inhibitory effect was more marked on E. coli. In general, the inhibitory effect of the $\mathrm{H}+$-ATPases proton pumps was more pronounced at $2 \mathrm{MIC}$ values.

3.2.3. Loss of Salt Tolerance Capacity. The salt tolerance potential of $S$. aureus in the presence of E. chlorantha extract or $n$-butanol fraction at different concentrations is shown in Figure 5. It can be observed that when the bacteria pretreated with extract were inoculated on culture media supplemented with different concentrations of $\mathrm{NaCl}$, a significant decrease in the number of colony-forming units was observed. Compared to other concentrations, the number of colonies formed 

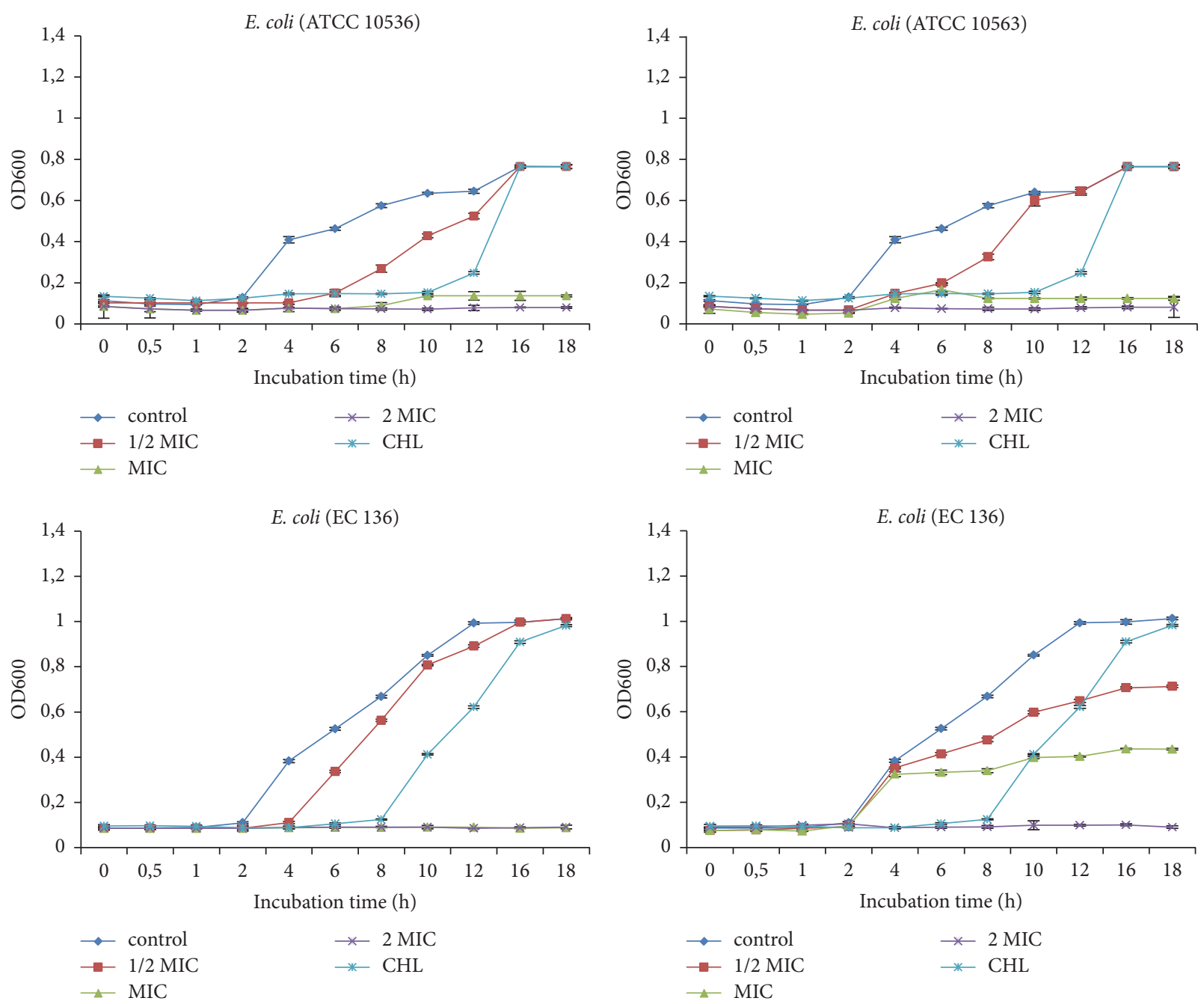

(a)

(b)

FIGURE 2: Effect of E. chlorantha methanol extract (a) and its n-butanol fraction (b) on Escherichia coli growth as a function of time. CHL: chloramphenicol; MIC: minimum inhibitory concentration. Data are expressed as mean; $n=3$.

on culture medium supplemented at $75 \% \mathrm{NaCl}$ was almost zero at 2 MIC.

3.2.4. Antibiofilm Activity. The extract and the n-butanol fraction have differently inhibited the E. coli biofilm formation (Figure 6). The inhibition was maximal (100\%) at 8 and $4 \mathrm{MIC}$ with crude extract. The n-butanol fraction was unable to inhibit all of the bacterial biofilm at 8 MIC.

3.2.5. Phytochemical Composition. The qualitative phytochemical composition showed that the methanol extract of E. chlorantha bark has at least seven classes of phytochemicals (Table 3). Alkaloids and triterpenes were found almost in all fractions, the other classes of secondary metabolites being selectively distributed. The n-butanol fraction was more rich in secondary metabolites in the same way as the crude extract followed by the residual fraction and the ethyl acetate fraction, respectively.

\section{Discussion}

The resistance of bacteria to usual antibiotics has led to a high incidence of treatment failures and a considerable increase in treatment costs [4]. Medicinal plants could be used as an alternative as their pharmacological properties including antimicrobial activity are well known [33].

The methanol extract of the E. chlorantha barks revealed significant antibacterial activities (MIC $<100 \mu \mathrm{g} / \mathrm{mL}$ ) on $14.29 \%$ of the microorganisms studied. This is enough evidence which highlights E. chlorantha bark as a source of antibacterial compounds.

Classification criteria for antimicrobial activity are numerous. According to Simões et al. [34], an extract is said to be antimicrobial when MIC is between 100 and $1000 \mu \mathrm{g} / \mathrm{mL}$. According to Aligiannis et al. [35], the activity of an extract is strong when MIC is less than $500 \mu \mathrm{g} / \mathrm{mL}$, moderate when MIC values ranged from $500 \mu \mathrm{g} / \mathrm{mL}$ to $1500 \mu \mathrm{g} / \mathrm{ml}$, and low when greater than $1500 \mu \mathrm{g} / \mathrm{mL}$. The 
TABLE 3: Extraction yields and phytochemical composition of methanol extract and fractions from E. chlorantha barks.

\begin{tabular}{|c|c|c|c|c|c|}
\hline \multirow{2}{*}{ Phytochemical groups } & \multirow{2}{*}{ Crude extract $(7.91 \%)$} & \multicolumn{4}{|c|}{ Fractions } \\
\hline & & FH (5.66\%) & FAE $(12.5 \%)$ & FBU $(20.87 \%)$ & FR $(39.71 \%)$ \\
\hline Alkaloids & + & - & + & + & + \\
\hline Anthocyanins & - & - & - & - & - \\
\hline Flavonoids & + & - & + & + & + \\
\hline Phenols & + & - & - & + & + \\
\hline Quinones & + & - & + & + & + \\
\hline Saponins & - & - & - & - & - \\
\hline Tannins & + & - & - & + & + \\
\hline Sterols & + & - & + & + & + \\
\hline Triterpenes & + & + & + & + & - \\
\hline
\end{tabular}

+: presence; -: absence, FH: n-hexane fraction, FAE: ethyl acetate fraction, FBU: n-butanol fraction, and FR: residual fraction.
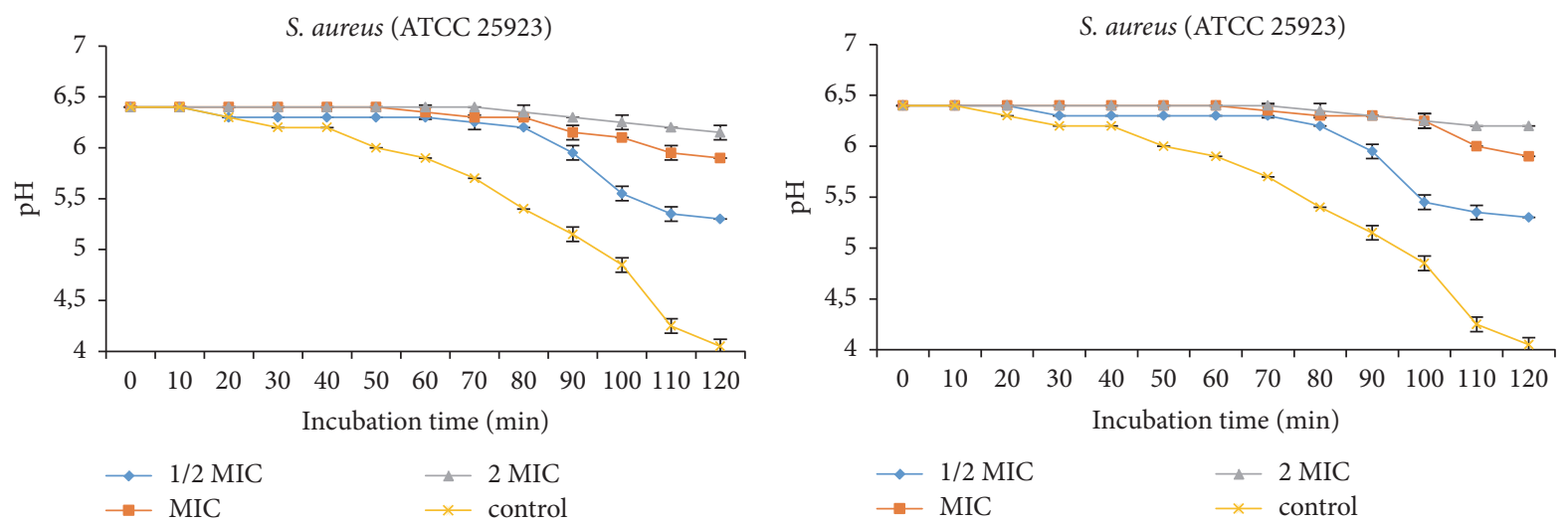

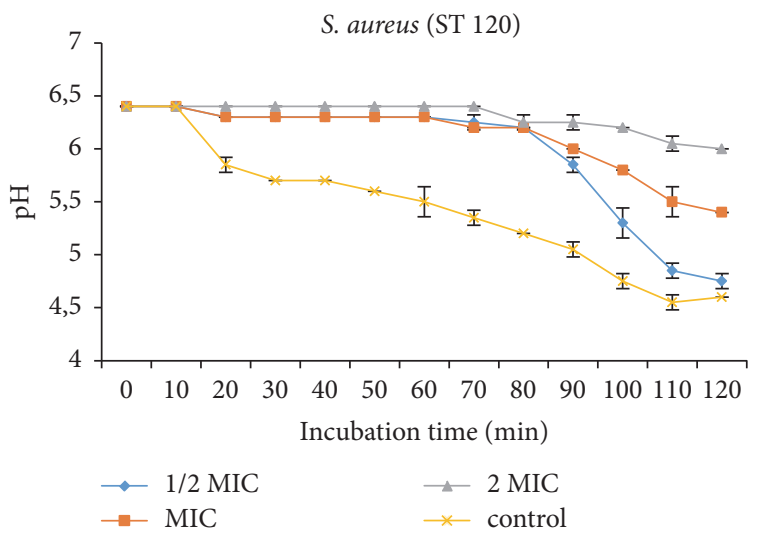

(a)

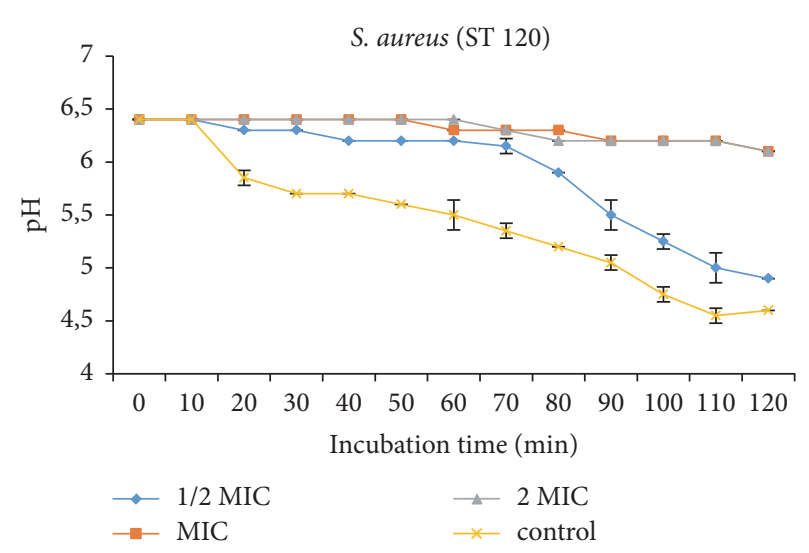

(b)

FIGURE 3: Effect of E. chlorantha methanol extract (a) and its n-butanol fraction (b) on Staphylococcus aureus proton pumping. MIC: minimum inhibitory concentration; data are expressed as mean $\pm \operatorname{SEM} n=3$; Ph was measured after 10 min preincubation.

scale proposed by Kuete [36], to which the present research referred, is much more restrictive. Whatever the case, the extract has significant antimicrobial activity meaning that it could be used to effectively fight against bacterial infections. The activity could be due to the different classes of phytochemicals found, their quantities, and the possible interactions with other constituents of the extract. Salmonella enterica serotype paratyphi A was the most sensitive isolate, whereas isolates from E. coli (EC 96), E. aerogenes (ENT 118), and S. aureus (MRSA 12) were found to be less sensitive. This suggests that the antibacterial activity of E. chlorantha extract is extended to both Gram- bacteria and S. aureus. Thus, the bacterial cell wall could have no effect on the activity of this extract.

The antimicrobial properties of a plant are influenced by several factors including the extraction solvent. Atata et al. [37] showed that aqueous, methanolic, and ethanolic extracts of $E$. chlorantha barks were active on different clinical 

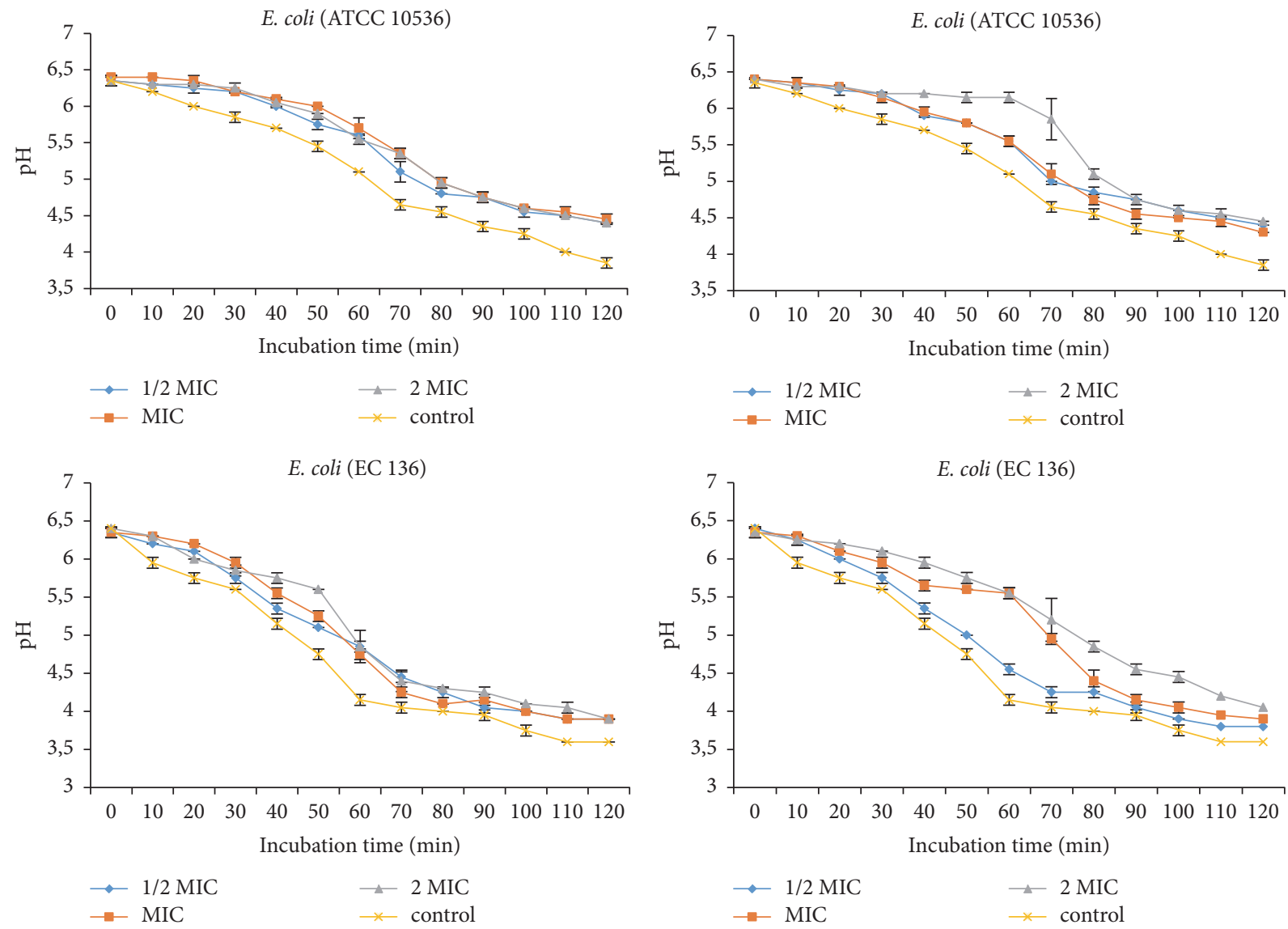

(a)

(b)

Figure 4: Effect of E. chlorantha methanol extract (a) and its n-butanol fraction (b) on Escherichia coli proton pumping. MIC: minimum inhibitory concentration; data are expressed as mean $\pm \operatorname{SEM} n=3$; Ph was measured after 10 min preincubation.

isolates with MIC values ranging from 25 to $150 \mathrm{mg} / \mathrm{mL}$ depending on the isolate and solvent used for extraction by the disk diffusion method. In the same order, Adesokan et al. [38] revealed that the aqueous bark extract of this plant has antibacterial activity against $S$. aureus, B. subtillis, E. coli, $P$. aeruginosa, and $S$. typhimurium with MIC values ranging between 25 and $105 \mathrm{mg} / \mathrm{mL}$. These values are very high compared to those reported elsewhere. Abdulsalami et al. [39] in Nigeria demonstrated that the methanol extract of both leaves and barks from E. chlorantha was active on $P$. aeruginosa, E. coli, and $S$. typhi with MIC values ranging from $12.5 \mathrm{mg} / \mathrm{mL}$ to $25 \mathrm{mg} / \mathrm{mL}$ by macrodilution method. Atukpawu and Ozah [40] revealed that the ethanol extract of stems, barks, and leaves was active with MIC values between 1.56 and $12.5 \mathrm{mg} / \mathrm{mL}$, while aqueous extract MIC ranged from 6.25 to $12.5 \mathrm{mg} / \mathrm{mL}$. The variability could be attributed to solvent used, antibacterial test method, the soil, and time of collection plant part. However the case, these findings suggest that active ingredients of E. chlorantha barks could be best extracted by polar solvents, thus carefully highlighting a necessity for a suitable choice of appropriate solvent for plant extraction of bioactive compounds together with the experimental methods.
The partition of methanol extract of E. chlorantha made it possible to obtain four fractions with varying degrees of activity. The n-butanol fraction and the aqueous residue revealed best antibacterial activities compared the crude extract and other fractions. This demonstrates that the nbutanol best concentrates the active ingredients responsible for the antibacterial activity. Therefore, the active ingredients responsible for the antibacterial activity could be of a polar nature. It will therefore be important to screen the antibacterial activity of the ethanol and water extract which express best yields [41]. In addition, this result reflects the role of fractionation in the search for antimicrobial from plants. Indeed, several alternatives have been mentioned including the exploration of crude extracts, the search for active fractions derived from crude extracts, and the research of active molecules from plants [8].

The most sensitive bacteria ( $\mathrm{MIC}=32 \mu \mathrm{g} / \mathrm{mL})$ to $\mathrm{n}$ butanol fraction were $S$. enterica serotype typhi (SAL9), P. aeruginosa (CIP 76110), and E. coli (EC 136) showing that this fraction could be used as an alternative to infections caused by these microorganisms because many cases of resistance to these germs are reported each year worldwide [42]. Furthermore, the activity of methanol extract and its 

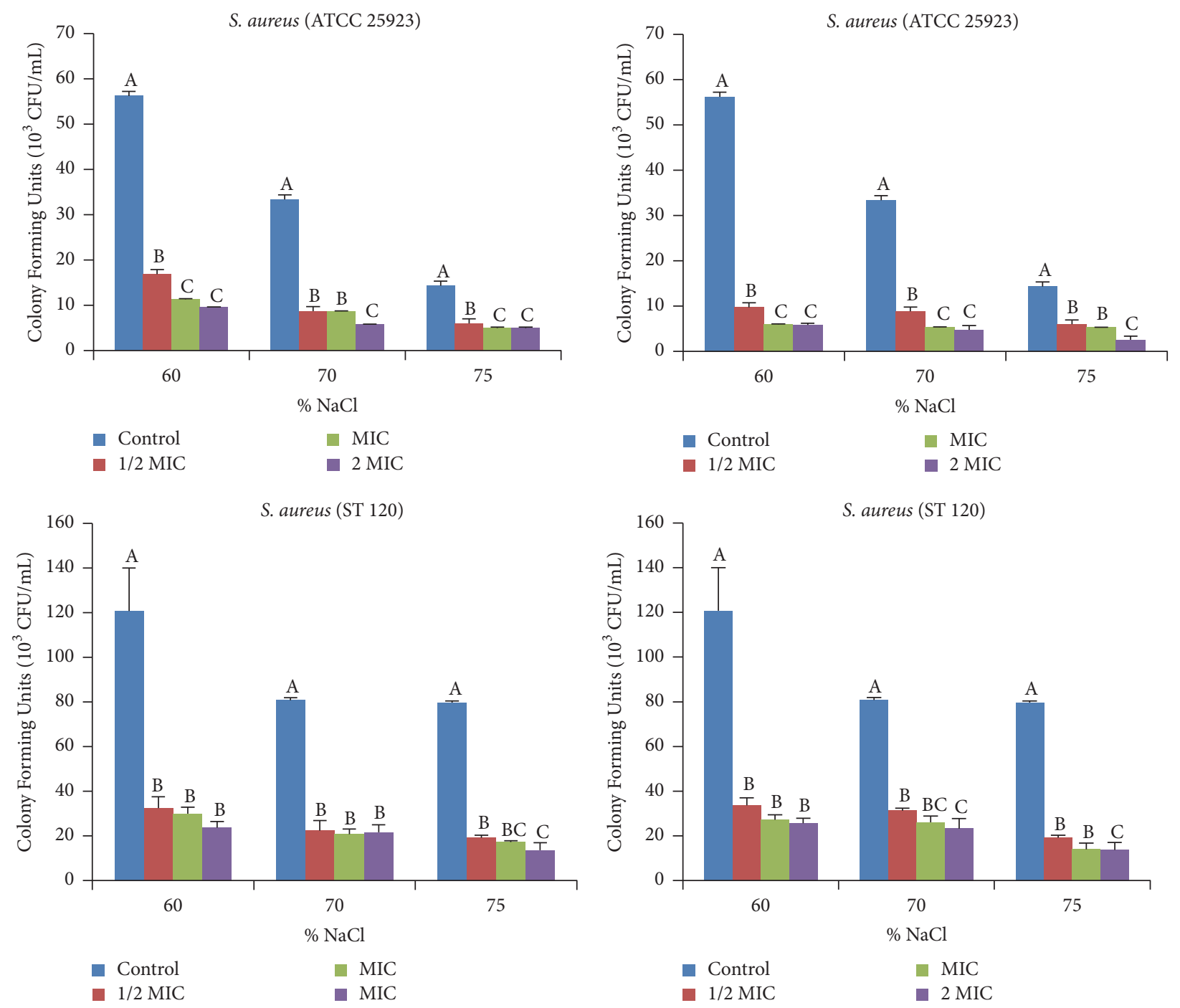

(a)

(b)

FIGURE 5: Effect of E. chlorantha methanol extract (a) and its n-butanol fraction (b) on the reduction of salt tolerance of Staphylococcus aureus. MIC: minimum inhibitory concentration; data are expressed as mean $\pm \operatorname{SEM} n=3$. Values with different superscript letters are significantly different at $p<0.05$ according to Waller Duncan.

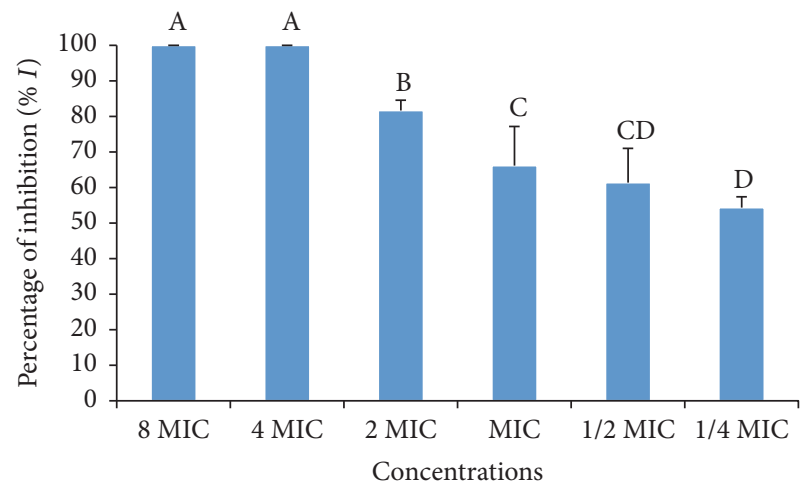

(a)

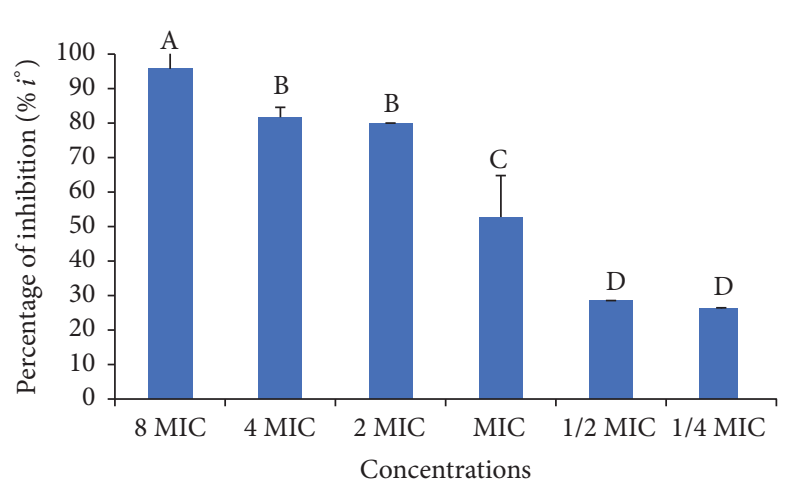

(b)

Figure 6: Antibiofilm effect of E. chlorantha methanol extract (a) and its n-butanol fraction (b) against Escherichia coli (EC 136). MIC: minimum inhibitory concentration; data are expressed as mean $\pm \operatorname{SEM} n=3$. Values with different superscript letters are significantly different at $p<0.05$ according to Waller Duncan. 
n-butanol fraction obtained on some multiresistant bacteria best valorize the E. chlorantha bark as a potent antibacterial since numerous researches indicate constant rise of resistant bacteria strains to common use antibiotics [5].

The MBC/MIC ratio is in most cases less than or equal to 4 meaning that the bactericidal activity of the methanol extract and n-butanol fraction from E-chlorantha could be expected.

Natural substances, due to the diversity of chemical they contain, act on bacteria cell constituents (membrane, wall) and/or on molecular targets (Ions or protons, proteins, DNA) by several action mechanisms [43].

Several authors showed that the inhibition of bacterial cell growth is one of the mechanisms that plant extracts explain their antibacterial activity. The growth curves illustrated that methanol extract and n-butanol fraction of E. chlorantha stem barks inhibited the growth of all bacteria used, the lag phase being prolonged up to 18 hours when extracts were added. The inhibition observed with Gram + bacteria was similar to Gram-bacteria showing that the cell membrane composition did not influence the antibacterial activity. Similar results were reported by Du et al. [44] and Darah et al. [27].

According to Silva and Fernandes [45], proton pumping constitutes target of choice for antimicrobial compounds. Inhibition of these pumps by plants extract demonstrates their bactericidal activity. In fact, cytoplasmic $\mathrm{pH}$ bacteria cells are regulated by extrusion proton via respiratory chain and potassium influx at acid $\mathrm{pH}$, and cation/proton antiporter regulates the $\mathrm{pH}$ in alkaline states [46]. Every substance that disturbs the regulation of ATPase responsible for maintaining the homeostasis and osmotic stability ions inside the cell are considered as a target of pumps proton. In this study E. chlorantha methanol extract and its nbutanol fraction inhibited the proton pumping $\mathrm{H}+$-ATPases of Gram + and Gram- bacteria, meaning that proton pumping is a possible target of this plant extract. Kuete et al. [28] and Tatsadjieu et al. [47] showed that some medicinal plants of Cameroon origin explain their antibacterial activity by inhibition of proton pumping.

The loss of salt tolerance in S. aureus after addition of plant extract explains the capacity of extract to disturb the capacity of bacteria to exclude salt from the cell. This is associated with alterations on the cell membrane. Rhamie and his coworkers [48] demonstrated that terpenoid compounds from Elephantopus scaber cause loss tolerance to cell membrane and explain her membranous target. Similar activity was also reported with essential oil of Enteromorpha linza Linn [29].

Biofilm formation in the environment is one of the mechanisms bacteria use to resist drugs and biocides. Many plants extract explain their bactericidal activity by the inhibition of biofilm formation. In the biofilm structure, plant extracts inhibit peptidoglycan synthesis and modulating the quorum sensing a whole of gene intervening in the regulation of biofilm formation [49]. In this study, total inhibition (100\%) of biofilm formation necessitated high concentration of crude extract (4 MIC). Comparing to the crude extract, the nbutanol fraction at 8 MIC inhibited only $80 \%$ of biofilm formation. The antibiofilm activity observed indicated that the antibiofilm compounds could be found in the crude methanol extract of E. chlorantha. Moreover, fractioning could reduce the capacity of this extract to explain the antibiofilm. Similar results were reported by Mohsenipour and Hassanshahian [31] with ethanol extract of Thymus vulgaris on E. coli.

Phytochemical screening of E. chlorantha stem barks revealed several compounds such as flavonoids, phenols, alkaloids, anthocyanins, steroids, quinones, saponins, tannins, and triterpenes. Their presence could explain the bactericidal mechanism of this plant extract.

\section{Conclusion}

The methanol extract of E. chlorantha bark has significant antibacterial activities on the microorganisms studied. This activity extends to Gram- bacteria and S. aureus strains and isolates. The n-butanol and aqueous residue fraction is more active compared to the crude extract. Considering all the studied action mechanisms both on Gram- and Gram+ bacteria, it appears that the methanol extract of E. chlorantha could have many compounds which could inhibit the cell growth by acting as inhibition of proton pump, cytoplasmic damage, and biofilm formation inhibition.

The coexistence of several modes of action expressed by the $n$-butanol fraction could explain its bactericidal activity.

\section{Conflicts of Interest}

The authors declare that there are no conflicts of interest regarding the publication of this article.

\section{Authors' Contributions}

Rebeca Ebelle Etame was the main field investigator. Raymond Simplice Mouokeu initiated the work and conceived the manuscript. Cedric Laurel Pouaha Cidjeu, Igor Kenfack Voukeng, Raphael Tchientcheu, Jean Paul Assam Assam, and Frank Stève Monthe Poundeu participated in the field work and in the manuscript writing. Alembert Tiabou Tchinda prepared plant extract and performed phytochemical tests. François Xavier Etoa, Jules Roger Kuiate, and Rosalie Anne Ngono Ngane designed the study, supervised the work, and participated in the manuscript writing.

\section{Acknowledgments}

The authors are grateful to Dr. Lawrence Oben Mbeng for English revision.

\section{References}

[1] P. N. Fonkwo, "Pricing infectious disease. The economic and health implications of infectious diseases," EMBO Reports, vol. 9, supplement 1, pp. S13-S17, 2008.

[2] P. Astagneau and T. Ancelle, "Surveillance épidémiologique: principes, méthodes et applications en santé publique," in Médecine Sciences Publications, p. 360, Paris, France, Lavoisier, 2011.

[3] S. Bevilacquia, Evaluation de l'impact d'une équipe opérationnelle en infectiologie sur la consommation et le coût des antibiotiques au CHU de Nancy [PhD Thesis], Université Henry 
Poincaré, 2011, Thèse de doctorat en science de la vie et de la santé.

[4] World Health Organization WHO, Antimicrobial Resistance, World Health Organization, Geneva, Switzerland, 2017, http://www.who.int/mediacentre/news/releases/2017/bacteriaantibiotics-needed/en/.

[5] E. Cerceo, S. B. Deitelzweig, B. M. Sherman, and A. N. Amin, "Multidrug-resistant gram-negative bacterial infections in the hospital setting: overview, implications for clinical practice, and emerging treatment options," Microbial Drug Resistance, vol. 22, no. 5, pp. 412-431, 2016.

[6] S. Gibbons, "Phytochemicals for bacterial resistancestrengths, weaknesses and opportunities," Planta Medica, vol. 74, no. 6, pp. 594-602, 2008.

[7] E. O. Iwalewa, M. M. Suleiman, L. K. Mdee, and J. N. Eloff, "Antifungal and antibacterial activities of different extracts of Harungana madagascariensis stem bark," Pharmaceutical Biology, vol. 47, no. 9, pp. 878-885, 2009.

[8] I. K. Voukeng, B. K. Nganou, L. P. Sandjo et al., "Antibacterial activities of the methanol extract, fractions and compounds from Elaeophorbia drupifera (Thonn.) Stapf. (Euphorbiaceae)," BMC Complementary and Alternative Medicine, vol. 17, no. 1, article 28, 2017.

[9] J. A. Seukep, L. P. Sandjo, B. T. Ngadjui, and V. Kuete, "Antibacterial activities of the methanol extracts and compounds from Uapaca togoensis against Gram-negative multi-drug resistant phenotypes," South African Journal of Botany, vol. 103, pp. 1-5, 2016.

[10] D. E. Djeussi, L. P. Sandjo, J. A. K. Noumedem, L. K. Omosa, B. T. Ngadjui, and V. Kuete, "Antibacterial activities of the methanol extracts and compounds from Erythrina sigmoidea against Gram-negative multi-drug resistant phenotypes," BMC Complementary and Alternative Medicine, vol. 15, no. 1, article 453, 2015.

[11] S. B. Tankeo, F. Damen, L. P. Sandjo, I. Celik, P. Tane, and V. Kuete, "Antibacterial activities of the methanol extracts, fractions and compounds from Harungana madagascariensis (Hypericaceae)," Journal of Ethnopharmacology, vol. 190, pp. 100-105, 2016.

[12] G. S. S. Njateng, Z. Du, D. Gatsing et al., "Antifungal properties of a new terpernoid saponin and other compounds from the stem bark of Polyscias fulva Hiern (Araliaceae)," BMC Complementary and Alternative Medicine, vol. 15, no. 1, article 25, 2015.

[13] T. D. Ngoudjou, A. M. Yameen, G. S. S. Njateng et al., "GC/MS analysis, Antisalmonellal potential of methanol leaf extracts of Tristemma mauritianum and infected with Salmonella typhi," International Journal of Pharmacy, vol. 7, no. 2, pp. 120-131, 2017.

[14] G. E. K. Bolou, B. Attioua, A. C. N'Guessan, A. Coulibaly, J. D. N'Guessan, and A. J. Djaman, "Évaluation in vitro de l'activité antibactérienne des extraits de Terminalia glaucescens planch. sur Salmonella typhi et Salmonella typhimurium," Bulletin de la Société Royale des Sciences de Liège, vol. 80, pp. 772-790, 2011.

[15] J. L. Betti, "Ethnobotanical study of medicinal plants among the baka pygmies in the Dja biosphere reserve," African Study Monographs, vol. 25, pp. 1-27, 2004.

[16] N. R. A. Ngono, M. M. L. Koanga, T. A. Tchinda et al., "Ethnobotanical survey of some Cameroonian plants used for treatment of viral diseases," African Journal of Plant Science, vol. 5, no. 1, pp. 15-21, 2011.

[17] T. Jiofack, I. Ayissi, C. Fokunang, N. Guedje, and V. Kemeuze, "Ethnobotany and phytomedicine of the upper Nyong valley forest in Cameroon," African Journal of Pharmacy and Pharmacology, vol. 3, no. 4, pp. 144-150, 2009.

[18] D. K. Olivier, S. F. Van Vuuren, and A. N. Moteetee, “Annickia affinis and A. chlorantha (Enantia chlorantha)-A review of two closely related medicinal plants from tropical Africa," Journal of Ethnopharmacology, vol. 176, pp. 438-462, 2015.

[19] T. J. O. Ngalani, Influence de la multi-résistance des bactéries entériques aux antibiotiques sur l'état immunologique des patients séropositifs au VIH venus en consultation à l'hôpital Adlucem Banka de Bafang [Master Thesis], Université de Dschang, 2015, Thèse de Master of Sciences de Biochimie.

[20] D. Gatsing and G. I. Adoga, "Antisalmonellal activity and phytochemical screening of the various parts of Cassia petersiana Bolle (Caesalpiniaceae)," Research Journal of Microbiology, vol. 2, no. 11, pp. 876-880, 2007.

[21] Q.-T. Tran, K. R. Mahendran, E. Hajjar et al., "Implication of porins in $\beta$-lactam resistance of Providencia stuartii," The Journal of Biological Chemistry, vol. 285, no. 42, pp. 3227332281, 2010.

[22] A. Paudel, H. Hamamoto, Y. Kobayashi, S. Yokoshima, T. Fukuyama, and K. Sekimizu, "Identification of novel deoxyribofuranosyl indole antimicrobial agents," The Journal of Antibiotics, vol. 65, no. 2, pp. 53-57, 2012.

[23] Clinical and Laboratory Standard Institute CLSI, Methods for Dilution Antimicrobial Susceptibility Tests for Bacteria That Grow Aerobically Approved Standard, vol. 35, 9th edition, 2015.

[24] J. N. Eloff, "A sensitive and quick microplate method to determine the minimal inhibitory concentration of plant extracts for bacteria," Planta Medica, vol. 64, no. 8, pp. 711-713, 1998.

[25] R. S. Mouokeu, R. A. N. Ngono, P. K. Lunga et al., "Antibacterial and dermal toxicological profiles of ethyl acetate extract from Crassocephalum bauchiense (Hutch.) Milne-Redh (Asteraceae)," BMC Complementary and Alternative Medicine, vol. 11, article 43, 2011.

[26] V. Kuete, F. Nana, B. Ngameni, A. T. Mbaveng, F. Keumedjio, and B. T. Ngadjui, "Antimicrobial activity of the crude extract, fractions and compounds from stem bark of Ficus ovata (Moraceae)," Journal of Ethnopharmacology, vol. 124, no. 3, pp. 556-561, 2009.

[27] I. Darah, S. H. Lim, and K. Nithianantham, "Effects of methanol extract of Wedelia chinensis osbeck (asteraceae) leaves against pathogenic bacteria with emphasise on Bacillus cereus," Indian Journal of Pharmaceutical Sciences, vol. 15, no. 5, pp. 533-539, 2013.

[28] V. Kuete, H. M. P. Poumale, A. N. Guedem, Y. Shiono, R. Randrianasolo, and B. T. Ngadjui, "Antimycobacterial, antibacterial and antifungal activities of the methanol extract and compounds from Thecacoris annobonae (Euphorbiaceae)," South African Journal of Botany, vol. 76, no. 3, pp. 536-542, 2010.

[29] J. K. Patra and K.-H. Baek, "Antibacterial activity and action mechanism of the essential oil from enteromorpha linza L. against foodborne pathogenic bacteria," Molecules, vol. 21, no. 3, article 388, 2016.

[30] G. A. O'Toole and R. Kolter, "Initiation of biofilm formation in Pseudomonas fluorescens WCS365 proceeds via multiple, convergent signalling pathways: a genetic analysis," Molecular Microbiology, vol. 28, no. 3, pp. 449-461, 1998.

[31] Z. Mohsenipour and M. Hassanshahian, "The effects of Allium sativum extracts on biofilm formation and activities of six pathogenic bacteria," Jundishapur Journal of Microbiology, vol. 8, no. 8, Article ID e18971, 2015. 
[32] J. B. Harbone, Phytochemical Methods: A Guide to Modern Techniques of Plant Analysis, Chapman and Hall Ltd, London, UK, 1973.

[33] A. G. Fankam, J.-R. Kuiate, and V. Kuete, "Antibacterial and antibiotic resistance modulatory activities of leaves and bark extracts of Recinodindron heudelotii (Euphorbiaceae) against multidrug-resistant Gram-negative bacteria," BMC Complementary and Alternative Medicine, vol. 17, no. 1, article 168, 2017.

[34] M. Simões, R. N. Bennett, and E. A. S. Rosa, "Understanding antimicrobial activities of phytochemicals against multidrug resistant bacteria and biofilms," Natural Product Reports, vol. 26, no. 6, pp. 746-757, 2009.

[35] N. Aligiannis, E. Kalpoutzakis, S. Mitaku, and I. B. Chinou, "Composition and antimicrobial activity of the essential oils of two Origanum species," Journal of Agricultural and Food Chemistry, vol. 49, no. 9, pp. 4168-4170, 2001.

[36] V. Kuete, "Potential of Cameroonian plants and derived products against microbial infections: a review," Planta Medica, vol. 76, no. 14, pp. 1479-1491, 2010.

[37] R. F. Atata, A. Sani, and S. M. Ajewole, "Effect of stem bark extracts of Enantia chloranta on some clinical isolates," Biokemistri, vol. 15, no. 2, pp. 84-92, 2003.

[38] A. A. Adesokan, M. A. Akanji, and M. T. Yakubu, "Antibacterial potentials of aqueous extract of Enantia chlorantha stem bark," African Journal of Biotechnology, vol. 6, no. 22, pp. 2502-2505, 2007.

[39] H. Abdulsalami, Y. A. Adebimpe, M. C. Dangana, M. B. Umar, and R. Abdulsalam, "Antibacterial evaluation of the methanolic extract of the leaf and stem bark of Enantia chlorantha," International Journal of Applied Biological Research, vol. 6, no. 2, pp. 62-70, 2014.

[40] C. P. Atukpawu and P. T. E. Ozah, "Antimicrobial studies of aqueous and ethanol extracts of Enantia chlorantha leaves and stem bark and their combined effect on selected bacteria and fungi," European Journal of Medicinal Plants, vol. 4, no. 9, pp. 1026-1045, 2014.

[41] A. O. Dawodu, U. D. Moses, A. Apena, A. Adetoro, and J. O. Daira, "The proximate evaluation and phytochemistry of Enantia chlorantha stem bark in aqueous and ethanolic extract," Middle-East Journal of Scientific Research, vol. 21, no. 11, pp. 2145-2148, 2014.

[42] Center of Food Security and Public Health CPSPH, Enterohemorrhagic Escherichia coli Infection, Iowa State University, 2009.

[43] P. Sumthong and R. Verpoorte, Developing Antimicrobial Compounds from Natural Sources, Institute of Biology Leiden University, 2007.

[44] W. Du, C. Sun, Z. Liang, Y. Han, and J. Yu, "Antibacterial activity of hypocrellin A against Staphylococcus aureus," World Journal of Microbiology and Biotechnology, vol. 28, no. 11, pp. 3151-3157, 2012.

[45] N. C. C. Silva and A. J. Fernandes, "Biological properties of medicinal plants: a review of their antimicrobial activity," Journal of Venomous Animals and Toxins including Tropical Diseases, vol. 16, no. 3, pp. 402-413, 2010.

[46] H. Kobayashi, "A proton-translocating ATPase regulates $\mathrm{pH}$ of the bacterial cytoplasm," The Journal of Biological Chemistry, vol. 260, no. 1, pp. 72-76, 1985.

[47] N. L. Tatsadjieu, P. M. J. Dongmo, M. B. Ngassoum, F.-X. Etoa, and C. M. F. Mbofung, "Investigations on the essential oil of Lippia rugosa from Cameroon for its potential use as antifungal agent against Aspergillus flavus Link ex. Fries," Food Control, vol. 20, no. 2, pp. 161-166, 2009.
[48] J. Rhamie, B. N. Selvakumar, and P. Daisy, "Investigating the mechanism of action of terpenoids and the effect of interfering substances on an Indian medicinal plant extract demonstrating antibacterial activity," International Journal of Pharmaceutical Sciences and Research, vol. 2, no. 2, pp. 19-24, 2011.

[49] C. Lu, B. Kirsch, C. Zimmer et al., "Discovery of antagonists of PqsR, a key player in 2-alkyl-4-quinolone- dependent quorum sensing in Pseudomonas aeruginosa," Chemistry \& Biology, vol. 19, no. 3, pp. 381-390, 2012. 


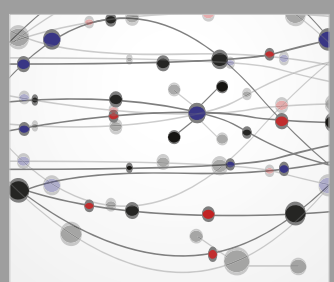

The Scientific World Journal
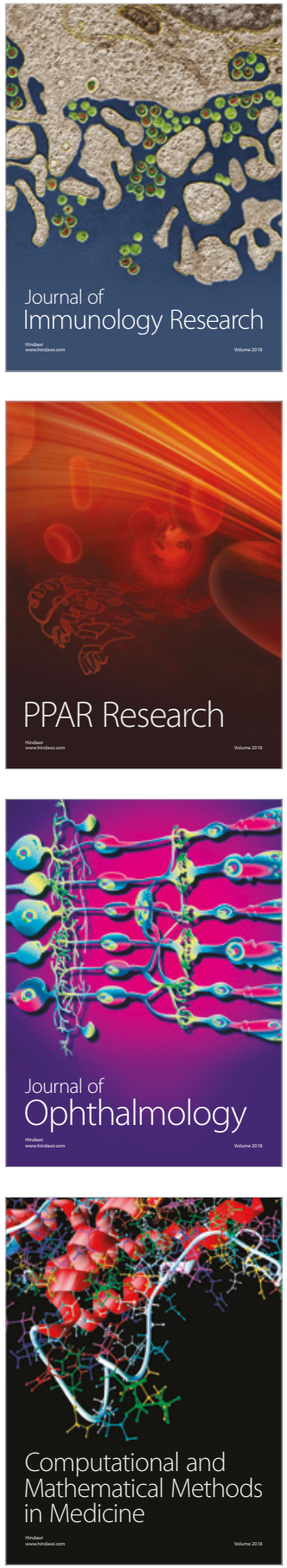

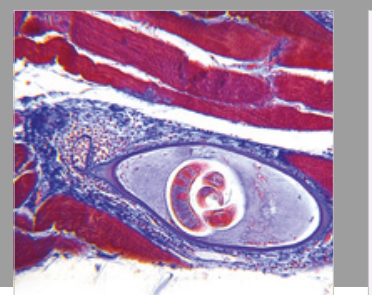

Gastroenterology Research and Practice

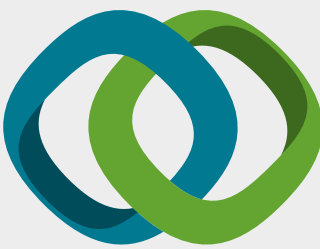

\section{Hindawi}

Submit your manuscripts at

www.hindawi.com
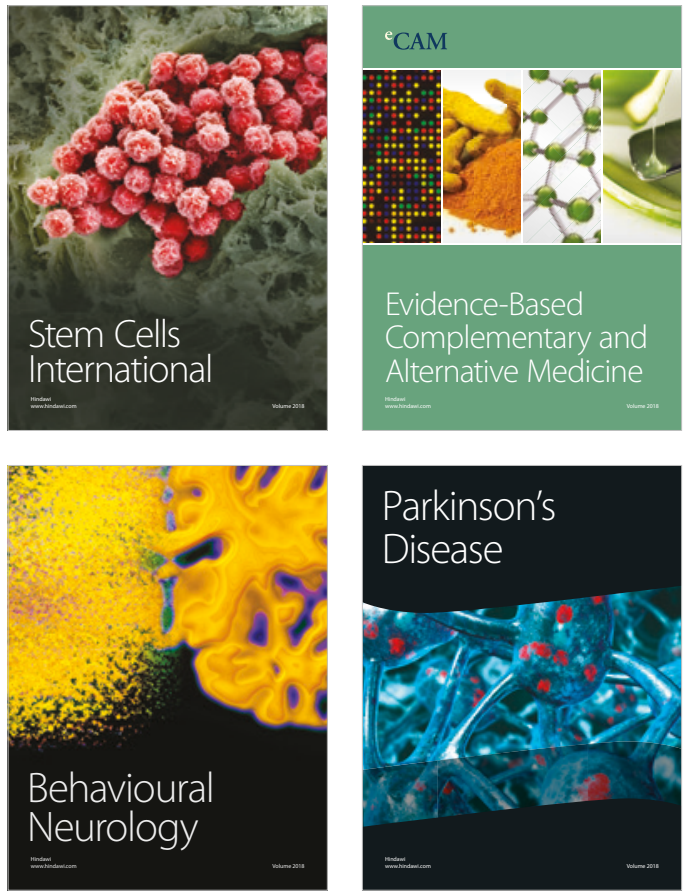

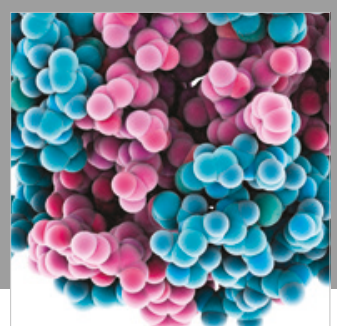

ournal of

Diabetes Research

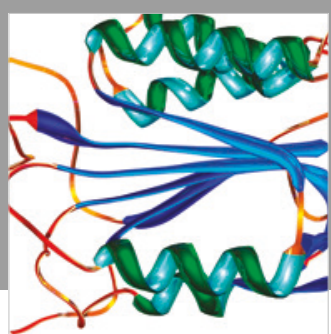

Disease Markers
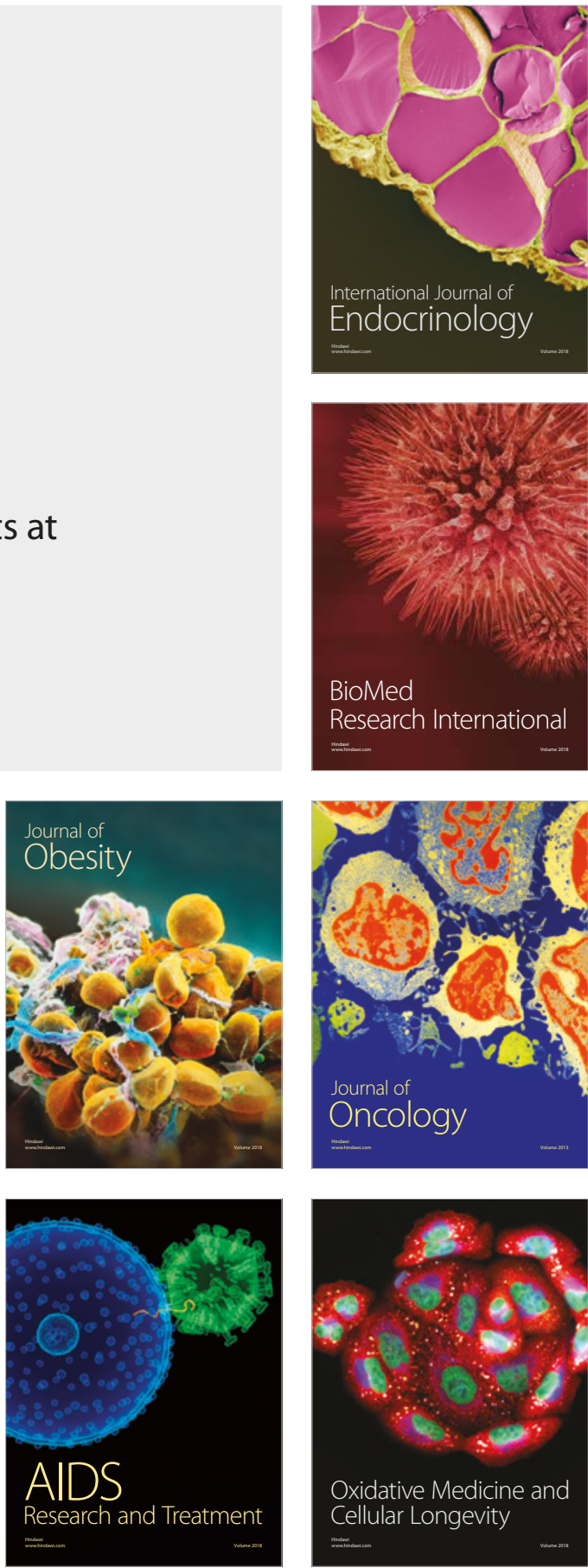